\title{
Programy resocjalizacyjne realizowane w polskich zakładach poprawczych i schroniskach dla nieletnich oraz ich ewaluacja
}

\begin{abstract}
Abstrakt
Artykuł składa się z dwóch części. W pierwszej scharakteryzowano rodzaje programów resocjalizacyjnych realizowanych w zakładach poprawczych i schroniskach dla nieletnich na terenie całego kraju. Bogactwu pomysłów, wielkiej różnorodności, szeroko realizowanej współpracy ze środowiskiem otwartym nie towarzyszy równie wysoki poziom ewaluacji programów. Autorzy prezentowanych programów, pisząc o efektywności resocjalizacyjnej swoich programów (jej analizie poświęcona jest część druga tekstu), powołują się na następujące jej wskaźniki: nabycie przez wychowanków określonej wiedzy, nowych i przydatnych umiejętności oraz określonych kompetencji społecznych. Odnotowanie tych wskaźników jest dla autorów programów jednoznaczne z uzyskaniem satysfakcjonującego rezultatu w procesie resocjalizacji. Formą rejestracji wskaźników jest w większości przypadków zastosowanie obserwacji niekontrolowanej (niestandaryzowanej). Tylko 9 programów na 59 posiadało formę ewaluacji opartą o narzędzia, które nie są obarczone takimi niedostatkami metodologicznymi, jak obserwacja niekontrolowana i były to: ankieta, test oraz studium indywidualnych przypadków. 9 programów nie posiadało żadnej formy ewaluacji, zaś w 20 zastosowano obserwację żywiołową (potoczną).
\end{abstract}

Słowa kluczowe: programy resocjalizacyjne, ewaluacja, zakład poprawczy, schronisko dla nieletnich.

\footnotetext{
* Uniwersytet Śląski w Katowicach.

** Uniwersytet Śląski w Katowicach.
} 


\title{
Correctional Programmes Implemented in Polish Juvenile Detention Centres and Juvenile Shelters and Their Evaluation
}

\begin{abstract}
The article consists of two parts. The first one describes types of rehabilitation programmes implemented in juvenile detention centres and juvenile shelters throughout the country. The richness of ideas, great diversity, and extensive cooperation with the open environment are not accompanied by an equally high level of programme evaluation. When writing about the rehabilitation effectiveness of their programmes (we deal with this in the second part of the text), the authors of the presented programmes refer to the following effectiveness indicators: acquisition of specific knowledge, new and useful skills, and specific social competences, by juveniles. For the authors, observation of these indicators in the programmes equates to obtaining a satisfactory result in the rehabilitation process. In most cases, indicators are registered using uncontrolled (unstructured) observation. Only 9 out of 59 programmes involved a form of evaluation based on tools that are not burdened with methodological deficiencies as opposed to uncontrolled observation; those tools included a questionnaire, a test and a case study. 9 programmes did not have any form of evaluation, while in 20 others, naturalistic observation was used.
\end{abstract}

Keywords: correctional programmes, evaluation, juvenile detention centres, juvenile shelters.

\section{Wprowadzenie}

Programy resocjalizacyjne realizowane w polskich zakładach poprawczych i schroniskach dla nieletnich (dalej ZP i SdN) cechuje duża wszechstronność (zob. Bernasiewicz, Noszczyk-Bernasiewicz 2018a). Ich szczegółowa analiza wskazuje na wysokie kwalifikacje kadry pedagogicznej i psychologicznej zatrudnionej w tych placówkach. Kwalifikacje te nie ograniczają się jedynie do formalnego wykształcenia uniwersyteckiego $\mathrm{w}$ dziedzinie nauk społecznych. Wykształcenie wyższe - co nie jest wcale normą w państwach Zachodu, a raczej wyjątkiem - jest w Polsce warunkiem koniecznym pracy na stanowisku wychowawcy (w internacie placówki resocjalizacyjnej). Tymczasem, jak szybko można się zorientować czytając kolejne programy, ich realizatorzy oprócz formalnego wykształcenia kierunkowego posiadają nierzadko dodatkowe wysokospecjalistyczne kompetencje do prowadzenia np. turystyki kwalifikowanej, zajęć z żeglarstwa, wspinaczki skałkowej, treningu sportowego, hodowli i pielęgnacji zwierząt czy zajęć muzycznych poparte doświadczeniem i udokumentowanymi osiągnięciami odniesionymi w tych dziedzinach. Największym mankamentem tych programów jest ich część ewaluacyjna.

Jeśli chodzi o wskaźniki osiągnięcia efektów w programach resocjalizacyjnych realizowanych w ZP i SdN w Polsce, to są one na ogół poprawnie określone i były 
nimi m.in. zajście konkretnej zmiany w sferze zachowania podopiecznych, czy też zaistnienie obiektywnych rezultatów (korzyści), jakie realizacja programu przyniosła otoczeniu społecznemu, na rzecz którego pracowali uczestnicy programu. Autorzy programów, które poddajemy analizie w dalszej części artykułu, pisząc o efektywności resocjalizacyjnej swoich programów, powołują się na takie jej wskaźniki, jak nabycie przez wychowanków określonej wiedzy, nowych i przydatnych umiejętności czy też określonych kompetencji społecznych. Odnotowanie tych wskaźników jest dla autorów jednoznaczne z uzyskaniem satysfakcjonującego rezultatu $\mathrm{w}$ procesie resocjalizacji. W znakomitej większości autorzy programów nie przedstawiają jednak wiarygodnych danych, świadczących o wystąpieniu owych wskaźników. Często występującą formą ich rejestracji była potoczna obserwacja lub przeprowadzenie ankiety dotyczącej satysfakcji oraz oceny zajęć w percepcji wychowanków, co z oczywistych względów nie stanowi obiektywnej formy pomiaru efektywności tych zajęć, których celem nie jest przecież tylko zadowolenie uczestników, ale przede wszystkim zajście zmiany w psychologicznym bądź społecznym wymiarze funkcjonowania nieletnich przestępców, którzy byli uczestnikami tych programów.

Należy przyznać rację twórcom programów, że ankiety, które przeprowadzają po ukończonych zajęciach mierzą czasem przyrost stanu wiedzy oraz pojawienie się nowych, korzystnych ze społecznego punktu widzenia poglądów u wychowanków, co stanowi już pewien wskaźnik efektywności. Natomiast nie jest nim ankieta satysfakcji z zajęć. Tak czy inaczej odnotowano istotny brak użycia naukowych narzędzi pomiaru efektywności resocjalizacyjnej w postaci testów czy też innych standaryzowanych narzędzi badania stopnia niedostosowania społecznego. Należy także nadmienić, że w opisywanych programach, poza jednym przypadkiem, brakowało pomiaru początkowego, który byłby przeprowadzony przed rozpoczęciem zajęć (tzw. pretest), bez którego w ogóle trudno mówić o zajściu zmiany. Prawidłowość tę odnotowaliśmy już w innym tekście (zob. Bernasiewicz, Noszczyk-Bernasiewicz 2018a: 14).

Charakteryzowane w prezentowanym artykule programy posiadają jeszcze jeden mankament. W dokonywanej ewaluacji wskazanych programów kadra pedagogiczna polskich ZP i SdN rzadko odnosi się do istniejących teorii psychologicznych, pedagogicznych czy socjologicznych. Tymczasem ewaluacja oprócz oceny efektywności danego programu służyć powinna również testowaniu teorii oraz odkrywaniu ciekawych i pouczających prawidłowości (Klaus, Kossowska 2013: 198).

\section{Uwagi metodologiczne}

W prezentowanych w tym miejscu badaniach analizą objęto 59 programów resocjalizacyjnych. Szczególnym zainteresowaniem objęto te elementy programów, które związane były z ich ewaluacją. Do analizy włączono wszystkie programy, 
które zebrano i zaklasyfikowano do opublikowania w całości przy okazji innego przedsięwzięcia badawczego (zob. Bernasiewicz, Noszczyk-Bernasiewicz 2018a). W przedsięwzięciu tym dobór programów miał charakter celowy, a obecność ewaluacji w programie nie odgrywała większej roli w doborze/odrzuceniu programu (znaczenie podrzędne). Stąd też analizowane w tym miejscu wzory ewaluowania można uznać za typowe dla programów resocjalizacyjnych realizowanych przez kadrę ZP i SdN.

Warto dodać, że w sygnalizowanym wyżej projekcie badawczym najlepsze programy wyselekcjonowano z szerszego materiału pozyskanego od kierownictwa 24 ZP i SdN. Inicjatywa zgromadzenia najlepszych programów realizowanych w placówkach tego typu wynikała $\mathrm{z}$ chęci wyłonienia wyróżniającego się dorobku polskich pedagogów resocjalizacyjnych pracujących w zamkniętych zakładach dla nieletnich i opublikowania ich w jednym tomie, co stało się przedsięwzięciem bez precedensu (tamże). Akcja ta uzyskała poparcie Departamentu Spraw Rodzinnych i Nieletnich Ministerstwa Sprawiedliwości (Wydział Nadzoru nad Zakładami dla Nieletnich i Opiniodawczymi Zespołami Sądowych Specjalistów) oraz patronat Ministra Sprawiedliwości.

W badaniach programów resocjalizacyjnych zastosowano metodę analizy treści. Analiza treści należy do metod jakościowych obok takich metod, jak: otwarty wywiad pogłębiony, metoda biograficzna, badanie dokumentów osobistych i obserwacja (Radziewicz-Winnicki 2001: 100). Podstawową jednostką analizy uczyniono ewaluację jako element, który powinien być składnikiem każdego dobrze skonstruowanego programu resocjalizacyjnego, czy szerzej interwencyjnego.

Podczas lektury programów kategoryzowano kolejno pojawiające się w nich sposoby ewaluowania (bądź brak takiego elementu w programie), aż uzyskano 4 typy - o nich w dalszej części tekstu - w obrębie których znalazły się wszystkie zastosowane w 59 programach sposoby (nie)ewaluowania efektów resocjalizacyjnych.

Warto jeszcze dodać, że tematyczne oraz teleologiczne spektrum analizowanych programów jest bardzo szerokie, ale zawsze ich beneficjentem ostatecznym jest nieletni przestępca, czyli osoba, która popełniła czyn karalny oraz przejawia wysoki stopień demoralizacji, zaś wcześniejsze formy interwencji (stosowane środki wychowawcze oraz inne reakcje podejmowane w środowisku otwartym) nie przyniosły oczekiwanych rezultatów.

Zaprezentowane $\mathrm{w}$ dalszej części artykułu informacje oraz fragmenty programów pochodzą z tych, które w całości opublikowane zostały we wcześniej opisanej publikacji (Bernasiewicz, Noszczyk-Bernasiewicz 2018a). W tym miejscu należy podkreślić, że $\mathrm{w}$ opisie bibliograficznym prezentowanych fragmentów, stanowiących ilustrację dla prowadzonych $\mathrm{w}$ artykule analiz, celowo zrezygnowano $\mathrm{z}$ prezentowania autora(ów) cytowanego tekstu oraz tytułu rozdziału, by niepotrzebnie nie stygmatyzować tych osób, którym czasem zarzucamy mankamenty w przygotowaniu poprawnie skonstruowanego programu ewaluacji. 


\section{Programy resocjalizacyjne realizowane w ZP i SdN i ich ewaluacja w świetle badań własnych}

Oprócz powszechnej praktyki wyposażania wychowanków SdN i ZP w kwalifikacje zawodowe oraz kompetencje poruszania się po nowoczesnym rynku pracy w placówkach tych realizuje się wiele innych, ogólnorozwojowych programów (zob. także Bernasiewicz, Noszczyk-Bernasiewicz 2018b). Należą do nich w szczególności:

- poezjoterapia (pisanie wierszy, opowiadań i wydawanie ich w formie tomików liryki bądź eseju);

- wydawanie gazetki szkolnej (redagowanie, autorstwo tekstów), pisanie listów (zob. także Król 2011);

- trening ról rodzicielskich (praca z symulatorem, fantomem niemowlęcia);

- trening zachowań prospołecznych (wolontariat na rzecz osób starszych lub dzieci niepełnosprawnych, wolontariat na rzecz zwierząt, uczestnictwo w życiu harcerstwa lokalnego, porządkowanie obiektów i terenów użyteczności publicznej, takich jak zamki, pałace, szpitale, sanatoria itp.);

- udział w ustrukturalizowanych zajęciach z socjoterapii;

- terapia i profilaktyka uzależnień;

- rekreacyjne i wyczynowe uprawianie sportów (kajakarstwo na wodach płynących i stojących, turystyka kwalifikowana piesza nizinna i górska, turystyka kwalifikowana rowerowa, narciarstwo, wspinaczka skałkowa);

- animaloterapia (np. dogoterapia);

- plastykoterapia;

- teatr resocjalizacyjny;

- film resocjalizujący;

- muzykoterapia, np. misy tybetańskie, konkursy rapu;

- biblioterapia.

Podczas analizy treści próbki badawczej, jaką było 59 programów resocjalizacyjnych, wygenerowano dwie główne kategorie ewaluacji. Na potrzeby dalszych analiz określono je jako: „ewaluację szeroko pojętą” i „ewaluację typowo resocjalizacyjną".

Pierwszą rozumieć można jako sposób oceny realizacji programu mierzony różnorodnymi efektami materialno-statystycznymi, takimi jak: liczba uczestników, poziom ich zadowolenia z zajęć, rodzaj wypracowanych $\mathrm{w}$ toku realizacji programów dóbr materialnych, poznanych i spenetrowanych miejsc (co w samo w sobie powinno wzbogacać kapitał kulturowy uczestników programu). Ostatnie dwa efekty mają charakter resocjalizacyjny, ale jeśli w programie nie wskazywano na użycie konkretnych narzędzi mierzących rzeczywisty przyrost wiedzy czy kompetencji uczestników programu, to ewaluację taką kategoryzowano jako szeroko pojętą. Sposób odnotowania wyników programu był efektem zastosowania obserwacji potocznej, którą można określić żywiołową. 
„Szeroko pojęta ewaluacja” jest nienaukową formą ewaluacji efektów resocjalizacyjnych, ponieważ opiera się na słabo udokumentowanym przyroście wiedzy, umiejętności oraz kompetencji u wychowanków ZP i SdN. Ewaluacja naukowa musi opierać się na użyciu określonych metod i narzędzi wskazanych w programie (na najniższym poziomie zaawansowania metodologicznego powinna to być przynajmniej obserwacja nieskategoryzowana) (szerzej np. Brzezińska, Brzeziński 2001). Za „ewaluacje typowo resocjalizacyjne” w analizowanych programach uznano te, które zostały przeprowadzone z wykorzystaniem z góry założonych kryteriów oceny, przede wszystkim zaś wystandaryzowanych narzędzi pomiaru oraz z użyciem obserwacji planowanej. Ponadto metodyka badań na potrzeby ewaluacji została przez autorów programów (mniej lub bardziej) precyzyjnie opisana.

Poniżej przedstawiono charakterystykę ilościową typów ewaluacji wyróżnionych po przeanalizowaniu wszystkich programów resocjalizacyjnych. Aż 9 programów (z 59 wszystkich) nie zawierało informacji, które pozwoliłyby uznać, że zastosowano któryś z powyższych wyróżnionych rodzajów ewaluacji. Oznacza to, że tyle programów posiadało poważny mankament, w zasadzie dyskwalifikujący program jako konstrukcję o określonej strukturze, w której ewaluacja jest warunkiem sine qua non jego poprawności. W dwóch programach opisano sposób ewaluacji, ale nie przedstawiono jej wyników, jakie przyniósł program, stąd zakwalifikowano je do jeszcze innej kategorii: „opis sposobu ewaluacji bez wyników”.

Tabela 1. Rodzaje ewaluacji dokonywanych w programach resocjalizacyjnych realizowanych w ZP i SdN w Polsce

\begin{tabular}{|l|c|}
\hline \multicolumn{1}{|c|}{ Typ ewaluacji } & Liczba programów \\
\hline Ewaluacja szeroko pojęta & 19 \\
\hline Ewaluacja typowo resocjalizacyjna & 29 \\
\hline Brak ewaluacji w programie & 9 \\
\hline Opis sposobu ewaluacji bez wyników & 2 \\
\hline
\end{tabular}

Źródło: badania własne.

Zdecydowana większość ewaluacji ma charakter ewaluacji typowo resocjalizacyjnych. Należy jednak dodać, że w tej kategorii ewaluacji znalazło się jedynie 9 programów, w których do ewaluacji użyto narzędzi standaryzowanych. Zatem w próbce 59 programów jedynie w 9 posłużono się ewaluacją z zastosowaniem z góry przygotowanych kryteriów oceny postępu, jaki przyniosło zastosowanie programu. W programach tych posłużono się badaniami ilościowymi (kwestionariuszem ankiety, testem wiedzy) bądź jakościowymi (arkusz obserwacji, rozmowa kierowana, case study, w których analizowano wszystkich badanych według z góry określonych kryteriów). Poniżej przedstawiono przykładowy opis tego typu ewaluacji opartych na różnym poziomie standaryzacji użytych narzędzi: 
W ostatnich badaniach ankietowych brało udział 12 wychowanków regularnie uczęszczających na zajęcia sekcji piłki nożnej przez okres nie krótszy niż 6 miesięcy. Z grupy tej tylko 1 osoba uczestniczyła w treningach sportowych przed pobytem w placówce. Tylko 4 osoby przed umieszczeniem ich w zakładzie poprawczym interesowały się sportem, oglądały relacje sportowe, czytały artykuły na temat sportu. Na podstawie tych badań stwierdzono, że w przypadku tej grupy chłopców czynnie sport po raz pierwszy w życiu zaczęło regularnie uprawiać 11 badanych (w porównaniu ze stanem poprzedzającym przyjście do placówki) (...) Także 11 na 12. ankietowanych wychowanków stwierdziło, że po meczu czują się bardziej odprężeni, spokojniejsi, co potwierdza realizację celu rozładowania napięcia, odreagowania emocjonalnego poprzez udział w zajęciach sportowych. Tyle samo wychowanków dzięki grze w piłkę nożną czuje się dowartościowanych oraz ważnych; 7 na 11 podopiecznych czuje się dzięki grze potrzebnych, 7 - akceptowanych. (...) Z kolei 11 na 12 wychowanków jest zdania, że możliwość występów w drużynie piłkarskiej pomaga im w podjęciu decyzji o powrocie z urlopu do placówki. (...) Aż 6 respondentów zauważyło, że występy w drużynie przyczyniły się do ich osobistych sukcesów (zob. Bernasiewicz, Noszczyk-Bernasiewicz 2018a: 84).

(...) Drugim wskaźnikiem realizacji celów programu jest zmiana postaw wychowanków uczestniczących w tej formie zajęć rejestrowana w arkuszach spostrzeżeń, opiniach okresowych i innej dokumentacji pedagogicznej. Trzecim, również łatwo mierzalnym, kryterium realizacji celów programu jest uczestnictwo wychowanków w różnego rodzaju przedsięwzięciach artystycznych z rozróżnieniem formy biernej (oglądanie wystaw, spektakli teatralnych, słuchanie koncertów itp.) oraz aktywnej (udział w konkursach plastycznych, zdobywanie w nich nagród, organizowanie własnych wystaw. (...) Z ankiet oraz rozmów przeprowadzonych $\mathrm{w}$ ramach ewaluacji $\mathrm{z}$ uczestnikami programu oraz ich wychowawcami wynika, że (...) (tamże: 114).

Przed przystąpieniem do realizacji programu przeprowadzono test wiedzy o tematyce programu. Okazało się, że nasi wychowankowie posiadają wiedzę cząstkową lub nie posiadają żadnej wiedzy na ten temat. Po zakończeniu realizacji programu przyszedł czas na ewaluację. Ponownie sprawdziliśmy wiedzę uczestników, stosując te same testy. Okazało się, że wychowankowie potrafili odpowiedzieć poprawnie na 70\% pytań. Badania kwestionariuszowe wychowanków pokazały duże zainteresowanie tematyką zajęć. Nieletni wykazali się aktywnością oraz sumiennie odrabiali zadania grupowe (tamże: 359).

W przyszłości można pomyśleć o większej liczbie zajęć praktycznych, np. spotkaniach dotyczących prowadzenia domu (m.in. wspólne ugotowanie obiadu). Warto byłoby również rozważyć zaproszenie byłych wychowanków, którzy już od kilku lat przebywają poza zakładem, pracują, mają swoje rodziny, aby swoimi doświadczeniami podzielili się z uczestnikami zajęć. Na koniec każdej edycji piszemy „case study” dla każdego uczestnika. Poniżej przedstawiamy jedno 
z nich: (...) Podczas kolejnych zajęć zaczęło zmieniać się jego nastawienie do przyszłości. (...) W czasie ćwiczenia polegającego na telefonie w sprawie pracy nie miał odwagi wykonać zadania. Jednocześnie był zawstydzony wobec postawy kolegi, który nie miał takich oporów. Twierdził, że na wolności poradzi sobie z tym zadaniem (tamże: 349 ).

W pozostałych 20 ewaluacjach, które zaliczono do kategorii „ewaluacja typowo resocjalizacyjna" posłużono się obserwacją niekontrolowaną. 0 obserwacji niekontrolowanej czy nieskategoryzowanej Janusz Sztumski (1999) pisze, że jest prowadzona bez narzędzi systematyzujących. Nie należy jednak utożsamiać jej z tzw. „obserwacją żywiołową”, ponieważ jest ona również obserwacją planową, ale przeprowadzaną swobodnie, w sposób taki, jaki „prowadzący uzna za właściwy w każdym konkretnym przypadku. Na skutek możliwości względnie swobodnego postępowania badającego trudno byłoby jednak innemu badaczowi powtórzyć tak przeprowadzoną obserwację lub skontrolować jej wyniki. I w tym można upatrywać pewnych niedostatków obserwacji niekontrolowanej” (tamże: 126-127). A zatem w pozostałych opisach „ewaluacji typowo resocjalizacyjnych” - przykłady zaprezentowano poniżej - zabrakło podania wyczerpującej charakterystyki metod i technik pozyskania danych oraz określenia wskaźników świadczących o zajściu efektów resocjalizacyjnych (zamiast tego stwierdzono expressis verbis, że użyto obserwacji; sposób jej użycia pozwolił jednak na stwierdzenie, że była to obserwacja niekontrolowana):

[Zajęcia - przyp. aut] przyczyniają się do poprawy sprawności ruchowej, wyposażają w zupełnie nowe dla nich umiejętności, pozwalają pokonywać własne ograniczenia, otwierają nowe horyzonty myślowe, a także pokazują dziewczętom nieznany dla nich świat. Podczas zajęć uczestniczki dowiadują się o istnieniu języka kaszubskiego (...). Dziewczęta uczą się komunikacji i współpracy, podziału ról i obowiązków, których efektem jest konstruktywne działanie najpierw w małych zespołach, stanowiących załogę kajaka, czy jachtu żaglowego (tamże: 34).

W całym okresie funkcjonowania programu dało się zauważyć osiąganie następujących efektów: poprawa zachowania wychowanków, którzy uczestniczyli w obozie oraz tych którzy mają szansę wyjechać w przyszłości na obóz, (...) zdobycie przez wychowanków umiejętności praktycznych (jazda na nartach, pływanie kajakiem, pływanie stylem grzbietowym oraz dowolnym w jeziorze, pływanie na desce windsurfingowej, wspinaczka) (tamże: 53).

Dawid nadał swojej lalce imię Łukasz. Otrzymując „dziecko”, był w miarę spokojny. Pytał o sprawy techniczne dotyczące opieki. Przygotował kącik dla „syna”. Był pozytywnie nastawiony do sytuacji, jednak można było odnieść wrażenie, że miał podejście bardziej zadaniowe niż emocjonalne. (...) Przyznał, że jest mu przykro, że „oddaje dziecko”, że nie da rady dłużej się nim opiekować. 
Uznał, że jest to bardzo wyczerpujące. Powiedział również, że w najbliższej przyszłości nie chciałby mieć jeszcze dziecka, „dopiero po trzydziestce” (tamże: 208).

Podczas części praktycznej nadał swojej „córce” imię Amelka. Bardzo emocjonalnie podchodził do opieki. Zadawał mnóstwo pytań. Wielokrotnie upewniał się, czy w dobrej pozycji trzyma „dziecko”, czy dobrze je ubiera itp. Każdą czynność wykonywał bardzo delikatnie. Można było odnieść wrażenie, że się cieszy, ale jednocześnie jest pełen niepokoju. (...) Po drugiej dobie Adam był zmęczony, ale można odnieść wrażenie, że zaadaptował się to nowej sytuacji. Uznał, że pierwsza noc była najgorsza. Z uśmiechem opowiadał, że potrafi już rozpoznać, kiedy „córka” jest głodna, a kiedy trzeba zmienić pieluchę czy ukołysać. Pozwalał sobie na „chwilę oddechu”, ale „dziecko” zostawiał w dobrych rękach (tamże: 208).

Dzięki udziałowi w programie wychowankowie uczą się także, że nie każda praca musi być wykonana za określoną gratyfikację. Doświadczają życzliwości ludzi, dla których pracują za darmo. Wykonując swoje prace, chłopcy mają poczucie, że biorą udział w wartościowym przedsięwzięciu, które wspiera innych - bardziej potrzebujących. Podopieczni często sami dopytują się, kiedy znów będą mogli wziąć udział w wolontariacie i coraz bardziej przykładają się do pracy. Dla wychowanków, którzy angażują się w regularną pomoc w wybranych ośrodkach, prace wolontariackie stanowią dodatkowy motywator zewnętrzny do zachowywania właściwej postawy i dbałości o należne zachowanie na co dzień (tamże: 274).

Jeśli chodzi o przykłady na „szeroko pojętą ewaluację” (było ich w sumie 19), to zaliczono do nich również te, które stwierdzają zajście określonych efektów resocjalizacyjnych (np. brak recydywy), lecz nie zawierają opisu zastosowanej metodologii użytej do wygenerowania konkluzji o braku powrotności do przestępstwa przez wychowanków (brak opisu okresu katamnezy, brak wskazania źródła pozyskania danych o braku przestępczości powrotnej, np. dane z KRK, czyli Krajowego Rejestru Karnego, etc. - wnioski oparto zatem na obserwacji potocznej). Stwierdzenia takie pojawiały się w niektórych programach i były prawdopodobnie przejawem luźnej obserwacji, prowadzonej przez kadrę placówek resocjalizacyjnych. Z rozmów z dyrektorami oraz wychowawcami pracującymi w ZP i SdN wielokrotnie odnotowywaliśmy, że nierzadko wyciągają oni takie wnioski ze źródeł nieformalnych (otrzymując listy od byłych wychowanków deklarujących funkcjonowanie bez konfliktu z prawem czy też z analiz postów publikowanych przez nich na Facebooku).

Poniżej przedstawiono fragment takiej ewaluacji, który mówi o „twardych” efektach resocjalizacyjnych (brak recydywy) bez podania źródła danych oraz metodologii, jaką zastosowano w generowaniu tego typu wniosku: 
W wyniku zaangażowania w realizację programu kajakowego wychowankowie opuszczający naszą placówkę w trybie art. 90 i art. 86 u.p.n. ${ }^{1}$ lepiej dawali sobie radę $\mathrm{w}$ swoim środowisku rodzinnym i nie powracali na drogę konfliktu z prawem (tamże: 29).

W większości z 19 przypadków, w których ewaluację oparto na obserwacji swobodnej, odnotowywano zajście zmiany w zachowaniu podopiecznych bez wyraźnego stwierdzenia, że prowadzano w tym zakresie jakąś obserwację:

W hostelu nikt za chłopców nie wykonuje czynności, które zapewniają normalne funkcjonowanie w późniejszym okresie. Wychowankowie uczą się zatem robić zakupy spożywcze, muszą zwracać uwagę na ceny po to, by nie przekroczyć budżetu, muszą nauczyć się planować swoje posiłki, odpowiednio je przygotować, muszą zwracać uwagę na ich różnorodność (tamże: 377).

Dzięki realizacji programu uzyskaliśmy: 1. Zwiększenie motywacji wychowanków do kontynuowania terapii i pracy nad sobą; 2. Poprawę relacji pomiędzy wychowankami w zakładzie; 3. Zmniejszenie zachowań agresywnych i autoagresywnych u wychowanków; 4. Podniesienie poziomu praktycznych umiejętności radzenia sobie w sytuacjach trudnych przez wychowanków; 5. Zmniejszenie liczby osób niepowracających z przepustek z powodu nadużywania substancji psychoaktywnych; 6. Większą otwartość wychowanków w kontaktach z kadrą (częstsze rozmowy, zwiększenie ilości zachowań asertywnych w grupie) (tamże: 287).

\section{Zakończenie}

Przeprowadzona analiza jakościowa 59 programów resocjalizacyjnych realizowanych w polskich ZP i SdN pozwoliła stwierdzić, że programy opatruje się najczęściej w część ewaluacyjną. Tylko 9 programów było pozbawionych tego elementu. Poziom jej realizacji należy ocenić jednak jako niewystarczający, ponieważ jedynie w 9 programach użyto standaryzowanych narzędzi badawczych, które pozwalają na porównanie skuteczności realizacji efektów resocjalizacyjnych z innymi programami oraz na powtórzenie ewaluacji przez innego badacza. Zdecydowana większość programów posługuje się albo obserwacją niekontrolowaną (jest to ocena planowa, zatem ma charakter naukowy) albo obserwacją swobodną (żywiołową, która jest nienaukową strategią oceny uzyskanych w programie wyników). W sumie oba rodzaje obserwacji zastosowano aż w 39 ewaluacjach.

Uzyskane wyniki analizy świadczą o tym, że pedagodzy praktycy skupiają się w swojej pracy na stronie realizacyjnej programu, traktując część ewaluacyjną jako

\footnotetext{
1 Ustawa z dnia 26 października 1982 r. o postępowaniu w sprawach nieletnich z późniejszymi zmianami (tekst jednolity Dz.U. 1982, Nr 35, poz. 228).
} 
drugoplanowy element realizacji programu. Wynika to najprawdopodobniej albo z braku wiedzy metodologicznej realizatorów programów lub słabo artykułowanego przez dyrekcję placówek, a także Ministerstwo Sprawiedliwości wymogu wysokiej jakości tej części programu, jaką jest ocena efektywności oddziaływania danego programu. W planie nadzoru pedagogicznego sprawowanego przez Ministra Sprawiedliwości nad zakładami poprawczymi i schroniskami dla nieletnich trudno znaleźć cele odnoszące się do badania efektywności resocjalizacji prowadzonej w tych placówkach, zaś pojęcie ewaluacji odnosi się raczej do oceny całokształtu funkcjonowania tych placówek (np. częstotliwość występowania wydarzeń nadzwyczajnych) (zob. https://www.gov.pl/web/sprawiedliwosc/plan-nadzoru-pedagogicznegosprawowanego-przez-ministra-sprawiedliwosci-na-rok-szkolny-20192020).

Brak potrzeby odpowiedzi na pytanie, co działa (what works?), które tak bardzo eksponowane jest dziś w prowadzeniu resocjalizacji opartej na dowodach (Burnett, Roberts 2004), jest największym mankamentem aktualnie realizowanych w resocjalizacji instytucjonalnej programów.

Dążąc do poprawy zastanej praktyki w tym zakresie, należałoby stworzyć narzędzia systemowe (potrzebna byłaby inicjatywa ze strony Ministerstwa Sprawiedliwości) pozwalające na powoływanie do zespołów realizujących programy w placówkach resocjalizacyjnych osób pracujących na uniwersytetach. Zapraszanie naukowców do udziału w prowadzeniu części ewaluacyjnej programów resocjalizacyjnych byłoby rękojmią poprawnie prowadzonej oceny efektywności tych programów.

\section{Bibliografia}

Bernasiewicz M., Noszczyk-Bernasiewicz M. (red.) (2018a) Dobre praktyki resocjalizacyjne $w$ polskich zakładach poprawczych i schroniskach dla nieletnich $w$ Polsce, Katowice, Wydawnictwo Uniwersytetu Śląskiego.

Bernasiewicz M., Noszczyk-Bernasiewicz M. (2018b) Ścieżki inkluzji społecznej nieletnich przestępców w warunkach placówki zamkniętej w: Tożsamość i edukacja. Społeczne konstrukcje i reprezentacje, A. Cybal-Michalska, Z. Melosik, T. Gmerek, W. Segiet (red.), Poznań, Wydawnictwo Naukowe UAM, s. 111-121.

Brzezińska, A., Brzeziński, J. (2001) Metodologiczne problemy ewaluacji programów profilaktycznych stosowanych wobec młodzieży w: Ewaluacja profilaktyki problemów dzieci i młodzieży, J. Ł. Grzelak. M. J. Sochocki (red.), Warszawa, Wydawnictwo Fundacji ETOH, s. 117-145.

Burnett R., Roberts C. (red.) (2004) What Works in Probation and Youth Justice, Portland-Oregon, Willan Publishing. 
Klaus W., Kossowska A. (2013) Skuteczność prowadzonych działań prewencyjnych, czyli co działa w praktyce w: Społeczno-polityczne konteksty współczesnej przestępczości w Polsce, K. Buczkowski, B. Czarnecka-Dzialuk, W. Klaus, A. Kossowska, I. Rzeplińska, P. Wiktorska, D. Woźniakowska-Fajst, D. Wójcik, (red.), Warszawa, Wydawnictwo Akademickie SADNO Spółka z o.o., s. 195-227.

Król A. (2011) „Łobuzy” listy pisza , „Dziennik Zachodni” z dn. 6 czerwca.

Radziewicz-Winnicki A. (2001) Oblicza zmieniającej się współczesności. Szkice z pedagogiki społecznej, etnologii edukacyjnej i socjologii transformacji, Kraków, Oficyna Wydawnicza „Impuls”.

Sztumski J. (1999) Wstęp do metod i technik badań społecznych, Katowice, Wydawnictwo Naukowe „Śląsk”.

\section{Źródła internetowe}

https://www.gov.pl/web/sprawiedliwosc/plan-nadzoru-pedagogicznego-sprawowanegoprzez-ministra-sprawiedliwosci-na-rok-szkolny-20192020 [dostęp: 14.11.2019]. 